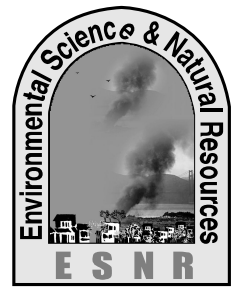

J. Environ. Sci. \& Natural Resources, 5(1): 223 - 227, 2012

ISSN 1999-7361

\title{
Influence of Different Media Variety and Growth Regulator on Mycelial Colony Proliferation of Mushroom
}

\author{
M. J. Uddin ${ }^{1}$, K. M. Nasiruddin ${ }^{2}$, M.E. Haque ${ }^{1}$, A. K. Biswas ${ }^{1}$ and M. S. Islam ${ }^{3}$ \\ ${ }^{1}$ Department of Agricultural Extension, ${ }^{2}$ Department of Biotechnology, BAU, Mymensingh \\ and ${ }^{3}$ Rajshahi Krishi Unnayan Bank, Natore
}

\begin{abstract}
An experiment was conducted at the Mushroom growth house and Tissue Culture Laboratory, Horticulture Demonstration and Training Centre (HDTC), Kewatkhali, Mymensingh during February to May, 2006 to investigate the mycelial colony proliferation of different mushroom species (Oyster (Pleurotus florida), Milky (Calocybe indica) and Button (Agaricus biporus)) in different media (viz. PDA, YPDA and MEA) and different combinations and concentrations ( 0, 1, 5, 10 and 20 ppm) of different growth regulators (IAA and NAA). As a media, the best mycelial growth of $9.34 \mathrm{~cm}$ was found in YPDA (Yeast Potato Dextrose Agar) at 21 DAI. As a variety, the best mycelial growth of $11.90 \mathrm{~cm}$ was performed by Oyster at 21 DAI. In case of combined effect of different media and variety for mycelial growth, the best growth $(12.57 \mathrm{~cm})$ was found in Oyster with YPDA media at 21 DAI. In case of growth regulator, the best mycelial growth of $5.50 \mathrm{~cm}$ was found at 21 DAI with $10 \mathrm{ppm}$ IAA and $4.03 \mathrm{~cm}$ was found at 18 DAI with $5 \mathrm{ppm}$ NAA and $5.38 \mathrm{~cm}$ at 21 DAI with control. In case of combined effect of IAA and NAA, the best mycelial colony proliferation $(6.72 \mathrm{~cm})$ was found with $10 \mathrm{ppm}$ IAA $+5 \mathrm{ppm}$ NAA at 21 DAI. It may be concluded that among three varieties and media, Oyster was the best variety and YPDA was the superior media for mushroom cultivation. Malt extract supplemented with 10 ppm IAA+ 5 ppm NAA as found to be the best for mycelial colony proliferation of Button mushroom.
\end{abstract}

Keywords: Button mushroom, Growth regulators, Media, Mycelial colony proliferation, Variety

\section{Introduction}

Mushrooms are valuable food, which are low in calories, high in vegetable proteins, zinc, chitin, fiber, vitamins and minerals (Alam and Saboohi, 2001). The mineral salt content in mushrooms is superior to that of meat and fish and nearly twice that of the most commonly used vegetables (Chang, 1972). Anticancer medicine (Leutinan) is produced recently by some chemical companies from the extract (Polysaccharides) of Shitake mushroom (Mori,1986). In Bangladesh, production of pulses decreased due to the adoption of large land area for rice production to fulfill the grain food demand of ever increasing population. Animal protein is beyond the reach of most people in this country because most of the people (over 86\%) live beyond poverty level (World Bank, 1992). So, the people are deprived of protein and suffer from malnutrition. Edible mushrooms are recommended by the FAO as food, to meet protein requirement of developing countries, the large proportion of which depends mainly on cereals (World Bank, 2004). In this situation if we can increase mushroom cultivation, it will ensure protein supply and greatly influence economic development and ultimately increase GDP as it saves times and space. Mushroom cultivation is a labour intensive indoor activity, which can help the landless, small and marginal farmers to raise their income, diversity economic activity and create gainful employment, especially for unemployed/under employed youth and women folk. Our country has resource and potential for large scale production of mushroom both for home consumption and export. Varietals difference was observed for mycelial colony proliferation of mushroom (Khandakar, 2004). Some growth regulators at different concentrations affect the yield and size of mushroom (Charles, 1986). Plant growth regulators and media can also play an important role for in vitro mycelial colony proliferation of mushroom (Maniruzzaman, 2004). Quite a large number of experiments have so far been carried out through out the world to find out the appropriate variety and media for mushroom cultivation. However, in the country sufficient research work have not yet been done on different variety and media for mushroom cultivation. The present piece of research work was, therefore, undertaken to investigate the mycelial colony proliferation of Oyster, Milky and Button mushrooms on PDA, YPDA and MEA (Malt Extract Agar) media and the effect of different combinations and concentrations of IAA and NAA on mycelial colony proliferation of Button mushroom.

\section{Methodology}

The experiment was conducted at the Mushroom growth house and Tissue Culture Laboratory, Horticulture Demonstration and Training Centre (HDTC), Kewatkhali, Mymensingh during February to May, 2006 to investigate the mycelial colony proliferation of different mushroom species (Oyster (Pleurotus florida), Milky (Calocybe indica) and 
Button (Agaricus biporus)) in different media (viz. PDA, YPDA and MEA) and different combinations and concentrations ( $0,1,5,10$ and $20 \mathrm{ppm}$ ) of different growth regulators (IAA and NAA). The mycelial colony diameter was observed to study the varietal, media and growth regulators performances at different days after inoculation (DAI). Media preparation methodology has been standardized with the method of Siddiqui (2002) with some modification. Sixteen combinations and concentrations of Indole Acetic Acid (IAA) at 0, 5, 10 and $20 \mathrm{ppm}$ and alpha-naphthalene Acetic Acid (NAA) at $0,1,5$ and $10 \mathrm{ppm}$ were supplemented in Malt extract agar medium as treatments only on Button mushroom where the growth regulators were treated as the levels of factor $\mathrm{A}$ and factor $\mathrm{B}$, respectively. Bottle containing media were packed tightly with non absorbent cotton then it was covered with paper placing rubber band. The bottles were sterilized for 2 hours at $121^{\circ} \mathrm{C}$ and $1.16 \mathrm{~kg} / \mathrm{cm}^{2}$ pressure in an autoclave and were kept 24 hours for cooling. Bottles containing different combinations and concentrations of growth regulators were sterilized in an autoclave for 1 hour at $121^{\circ} \mathrm{C}$ and then kept in a slant position for keeping the organism in pure culture. Then a piece of agar media $(1-2 \mathrm{~cm})$ containing mycelia as placed aseptically through the mouth of the bottles. The bottles plugged with cotton, were kept on wooden rake in laboratory room at 20$22^{\circ} \mathrm{C}$ for spawn run. After 10 day on wooden rake in laboratory room at $20-22^{\circ} \mathrm{C}$, the whole substrate became white due to fungal mycelia and then it (mother culture) was ready for spawning the different media. Media containing bottles were divided into three groups and each group consisted of three bottles. A small bit $(1 \mathrm{~cm})$ of mother culture of each mushroom species was lifted on flame into the bottle. It was done in the Laminar Airflow Cabinet. Then the bottles were kept on the wooden rake at $20-22^{\circ} \mathrm{C}$ for 21 days. All instruments, glassware and culture media were sterilized by autoclaved with $15 \mathrm{PSI}$ at $121^{\circ} \mathrm{C}$ for 1-2 hours. The culture room of the laboratory was cleaned by gently washing with detergent followed by $70 \%$ ethyl alcohol regularly. The diameter of mycelial colony was measured in centimeter from outside of the bottles by a scale at 3 days interval during the growing season from days after inoculation (DAI). Recorded data were statistically analyzed following Completely Randomized Design (CRD). The analysis of variance was performed and means were compared by Least Significant Difference (LSD) test at 5\% level probability for interpretation of results (Gomez and Gomez, 1984).

\section{Results and Discussion}

\section{Effect of variety}

The mean values for mycelial colony diameter of three varieties were found statistically significant. At $3,6,9,12,15,18$ and 21 DAI the diameter of mycelial colony was the highest in Oyster followed by Milky and the lowest was in Button. These results indicated that the colony diameter increased gradually with the advancement of time in all varieties (Figure 1). Oyster mushroom exhibited its clear superiority over the other 2 varieties throughout the entire cultivation period. The result was similar to the result of Islam et al, (2007) who observed the best colony proliferation in Oyster mushroom. The Button mushroom exhibited not inferior performance with regard to colony diameter.

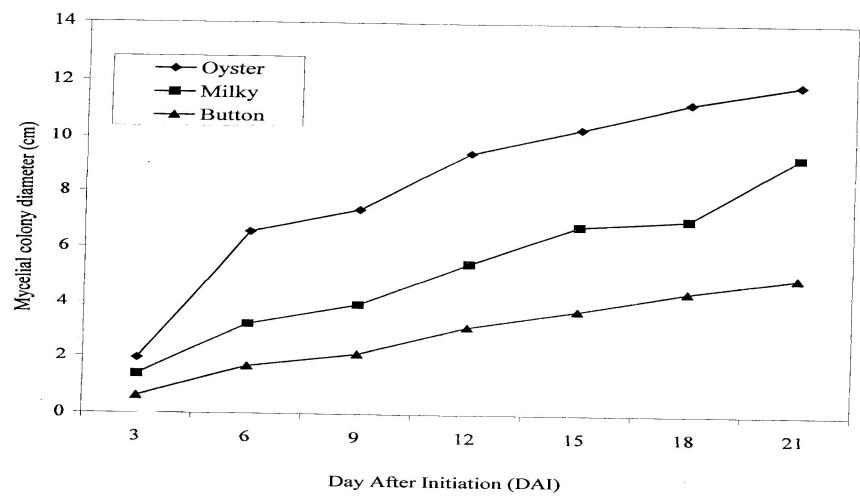

Fig. 1. Main effect of different varieties on mycelial colony proliferation 


\section{Effect of media}

The mean values of three media were found statistically non-significant for mycelial colony diameter at 3, 6, 9, 12, 15 and $18 \mathrm{DAI}$, indicating that there is no-significant variation among the media for mycelial colony growth at the above mentioned DAI. At 21 DAI, comparatively better performance of mycelial colony diameter $(9.344 \mathrm{~cm})$ was found in
YPDA, followed by MEA $(8.533 \mathrm{~cm})$ and PDA $(8.278 \mathrm{~cm})$, respectively (Fig. 2). Maniruzzaman (2004) observed the same result that the best mycelial colony proliferation with YPDA media in Oyster mushrooms. The findings is in the line with Nasim et $a l, 2001$ that PDA provided slower mycelial growth rates of Pleurotus ostreatus than MEA.

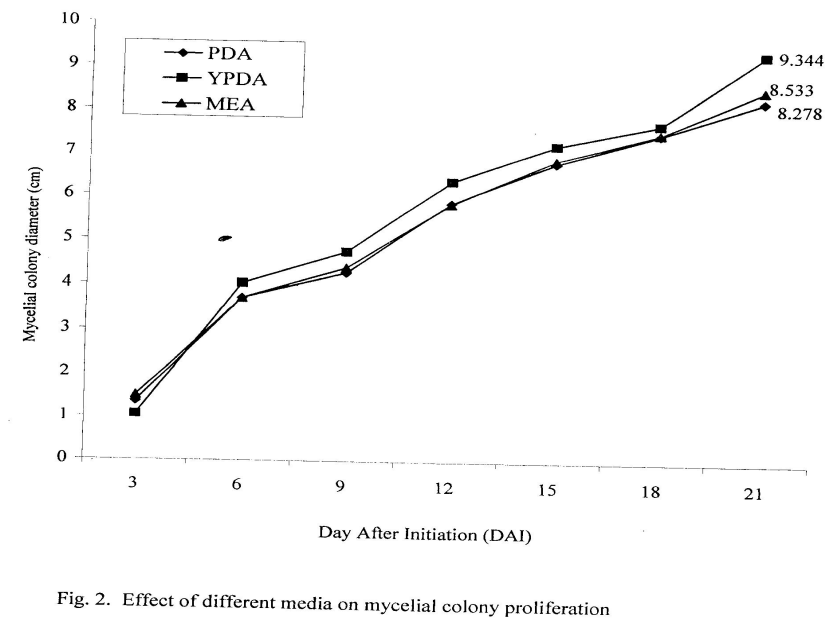

\section{Combined effect of variety and media}

The combined effects of different variety and media on mycelial growth were significant at all the 7 DAI. At 3 and 21 DAI, the best performance 2.67 and $12.57 \mathrm{~cm}$ were found with MEA $\times$ Oyster and Oyster $\times$ PDA respectively. But YPDA $\times$ Oyster showed the best performance $7.02,7.57,9.67,10.50$ and 11.37 $\mathrm{cm}$ at the rest $6,9,12,15$ and 18 DAI respectively (Table 1). Similar result was reported by Maniruzzaman (2004).

Table 1. Combined effect of variety and media on mycelium colony proliferation at different days after inoculation (DAI)

\begin{tabular}{|c|c|c|c|c|c|c|c|c|}
\hline Variety & Media & $\begin{array}{c}3 \\
\text { DAI }\end{array}$ & $\begin{array}{c}6 \\
\text { DAI }\end{array}$ & $\begin{array}{c}9 \\
\text { DAI }\end{array}$ & $\begin{array}{c}12 \\
\text { DAI }\end{array}$ & $\begin{array}{c}15 \\
\text { DAI }\end{array}$ & $\begin{array}{c}18 \\
\text { DAI }\end{array}$ & $\begin{array}{c}21 \\
\text { DAI }\end{array}$ \\
\hline \multirow{3}{*}{ Oyster } & PDA & $2.00 \mathrm{~b}$ & $6.000 \mathrm{~b}$ & $7.07 \mathrm{a}$ & $9.33 \mathrm{a}$ & $10.33 \mathrm{a}$ & $10.92 \mathrm{~b}$ & $11.37 \mathrm{~b}$ \\
\hline & YPDA & $1.71 \mathrm{~cd}$ & $7.017 \mathrm{a}$ & $7.57 \mathrm{a}$ & $9.67 \mathrm{a}$ & $10.50 \mathrm{a}$ & $11.37 \mathrm{a}$ & $12.57 \mathrm{a}$ \\
\hline & MEA & $2.67 \mathrm{a}$ & $6.683 \mathrm{ab}$ & $7.47 \mathrm{a}$ & $9.33 \mathrm{a}$ & $10.72 \mathrm{a}$ & $11.17 \mathrm{~b}$ & $11.70 \mathrm{~b}$ \\
\hline \multirow[t]{3}{*}{ Milky } & PDA & $1.58 \mathrm{bc}$ & $3.67 \mathrm{c}$ & $4.03 \mathrm{bc}$ & $5.50 \mathrm{~b}$ & $6.33 \mathrm{~b}$ & $7.00 \mathrm{c}$ & $8.83 \mathrm{~d}$ \\
\hline & YPDA & $1.25 \mathrm{~cd}$ & $3.50 \mathrm{c}$ & $4.35 \mathrm{~b}$ & $5.67 \mathrm{~b}$ & $7.83 \mathrm{~b}$ & $7.50 \mathrm{c}$ & $10.33 \mathrm{c}$ \\
\hline & MEA & $1.25 \mathrm{~cd}$ & $2.50 \mathrm{~d}$ & $3.47 \mathrm{c}$ & $5.25 \mathrm{~b}$ & $6.67 \mathrm{~b}$ & $6.37 \mathrm{c}$ & $8.67 \mathrm{~d}$ \\
\hline \multirow[t]{3}{*}{ Button } & PDA & $0.50 \mathrm{e}$ & $1.45 \mathrm{e}$ & $1.75 \mathrm{~d}$ & $2.75 \mathrm{~d}$ & $3.38 \mathrm{c}$ & $4.21 \mathrm{~d}$ & $4.63 \mathrm{f}$ \\
\hline & YPDA & $0.77 \mathrm{de}$ & $1.65 \mathrm{de}$ & $2.33 \mathrm{~d}$ & $3.75 \mathrm{c}$ & $3.90 \mathrm{c}$ & $4.17 \mathrm{~d}$ & $5.00 \mathrm{ef}$ \\
\hline & MEA & $0.57 \mathrm{e}$ & $1.93 \mathrm{de}$ & $2.25 \mathrm{~d}$ & $2.93 \mathrm{~d}$ & $4.40 \mathrm{c}$ & $4.83 \mathrm{~d}$ & $5.33 \mathrm{e}$ \\
\hline
\end{tabular}

The common letter(s) in a column did not differ at the level of 5\% probability as per DMRT.

\section{Effect of IAA on Button mushroom}

At 3, 6, 9, 12 and $21 \mathrm{DAI}$, the best performance of mycelial colony diameter $0.550,1.531,2.246,2.929$ and $5.504 \mathrm{~cm}$, respectively was found at $10 \mathrm{ppm}$ IAA.
But at 15 and 18 DAI, it was observed 3.500 and $3.908 \mathrm{~cm}$, respectively at 20 ppm IAA (Figure 3). Maniruzzaman (2004) in his study found the best mycelial growth at 5 ppm IAA in Oyster mushroom. 


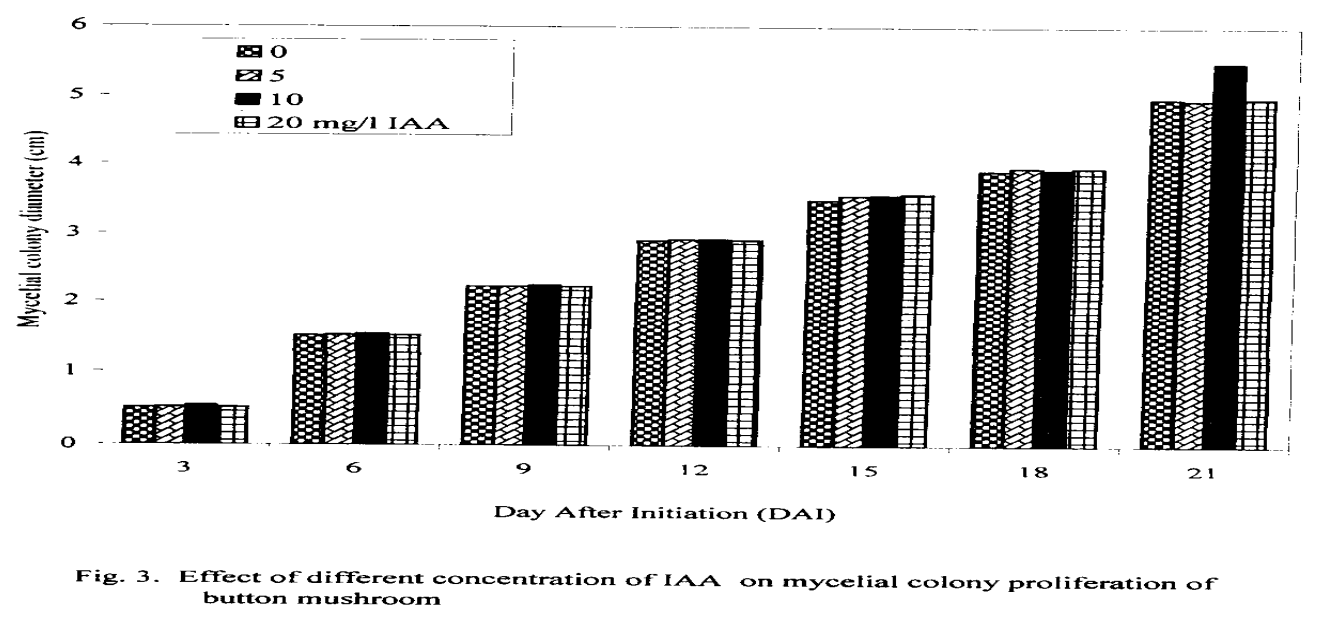

\section{Effect of NAA on Button mushroom}

At 3, 6, 9, 12, 15 and $18 \mathrm{DAI}$, the best performance of mycelial colony diameter $0.583,1.583,2.337,2.975$, 3.608 and $4.033 \mathrm{~cm}$, respectively was found at $5 \mathrm{ppm}$ NAA. But at 21 DAI, it was observed $5.388 \mathrm{~cm}$ at control (Figure 4). Chodchoi (1986) observed the best mycelial growth of Ear mushroom (Auricularia polytricha) with NAA at $10 \mathrm{ppm}$. The result of the present study did not comply with those findings possibly because of varietal difference.

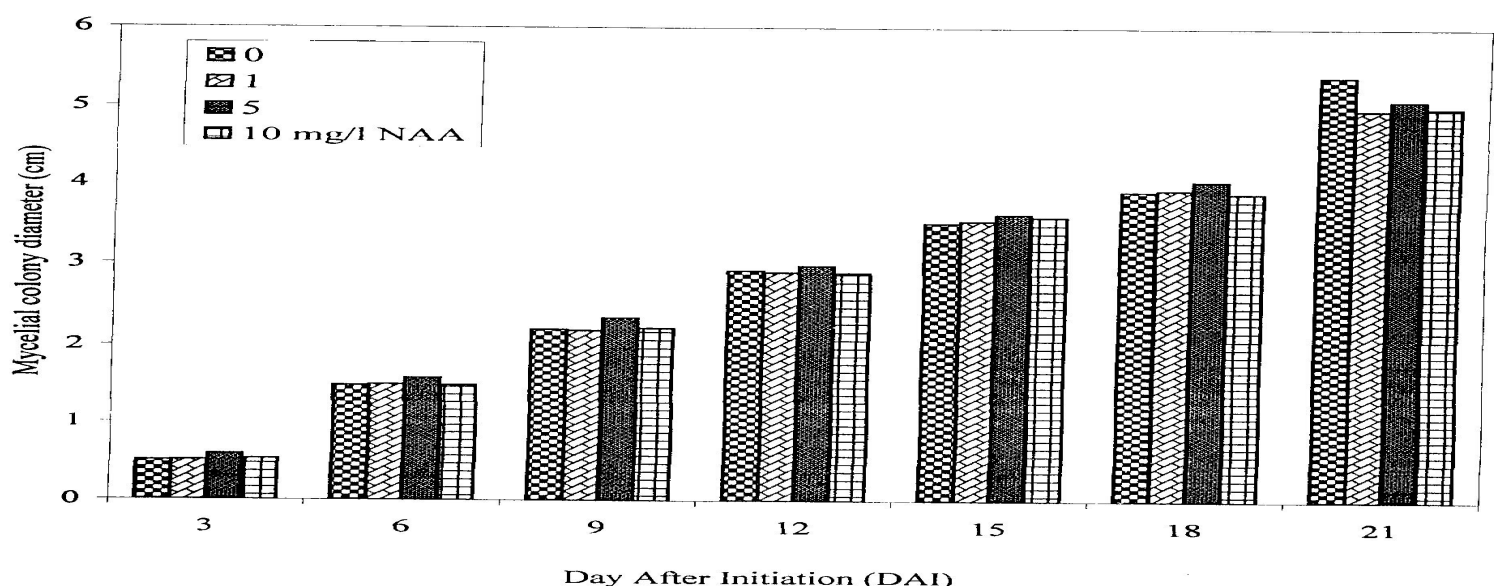

Fig. 4. Effect of different concentration of NAA on mycelial colony proliferation of button mushroom

Combined effect of IAA and NAA

The best performance of IAA and NAA $(0.67,1.66$, $2.37,3.00,3.70,4.22$ and $6.72 \mathrm{~cm}$ ) was found with 10 ppm IAA + 5 ppm NAA at 3, 6, 9, 12, 15, 18 and 21
DAI, respectively (Table 2). Maniruzzaman (2004) found the best mycelial colony diameter (MCD) at 5 ppm IAA + 0 ppm NAA in Oyster mushroom. 
Table 2. Combined effect of IAA and NAA on mycelium colony proliferation of Button mushroom at different days after inoculation (DAI)

\begin{tabular}{|c|c|c|c|c|c|c|c|c|c|}
\hline Treatment & $\begin{array}{c}\text { IAA } \\
(\mathrm{mg} / \mathrm{l})\end{array}$ & $\begin{array}{l}\mathrm{NAA} \\
(\mathrm{mg} / \mathrm{l})\end{array}$ & $\begin{array}{c}3 \\
\text { DAI }\end{array}$ & $\begin{array}{c}6 \\
\text { DAI }\end{array}$ & $\begin{array}{c}9 \\
\text { DAI }\end{array}$ & $\begin{array}{c}12 \\
\text { DAI }\end{array}$ & $\begin{array}{c}15 \\
\text { DAI }\end{array}$ & $\begin{array}{c}18 \\
\text { DAI }\end{array}$ & $\begin{array}{c}21 \\
\text { DAI }\end{array}$ \\
\hline $\mathrm{T}_{1}$ & \multirow[t]{4}{*}{0} & 0 & $0.50 \mathrm{ab}$ & 1.51 & 2.2 & 2.97 & $3.43 \mathrm{c}$ & $3.63 \mathrm{~b}$ & $4.90 \mathrm{~b}$ \\
\hline$T_{2}$ & & 1 & $0.50 \mathrm{ab}$ & 1.52 & 2.25 & 2.92 & $3.47 \mathrm{bc}$ & $3.90 \mathrm{ab}$ & $4.98 \mathrm{~b}$ \\
\hline$T_{3}$ & & 5 & $0.57 \mathrm{ab}$ & 1.57 & 2.33 & 2.97 & $3.53 \mathrm{abc}$ & $3.93 \mathrm{ab}$ & $5.10 \mathrm{~b}$ \\
\hline $\mathrm{T}_{4}$ & & 10 & $0.50 \mathrm{ab}$ & 1.53 & 2.20 & 2.87 & $3.57 \mathrm{abc}$ & $3.93 \mathrm{ab}$ & $4.92 \mathrm{~b}$ \\
\hline $\mathrm{T}_{1}$ & \multirow[t]{4}{*}{5} & 0 & $0.50 \mathrm{ab}$ & 1.53 & 2.25 & 2.90 & $3.53 \mathrm{abc}$ & $3.88 \mathrm{ab}$ & $4.95 \mathrm{~b}$ \\
\hline $\mathrm{T}_{2}$ & & 1 & $0.52 \mathrm{ab}$ & 1.47 & 2.13 & 2.90 & $3.53 \mathrm{abc}$ & $3.93 \mathrm{ab}$ & $4.93 \mathrm{~b}$ \\
\hline $\mathrm{T}_{3}$ & & 5 & $0.57 \mathrm{ab}$ & 1.60 & 1.35 & 2.97 & $3.61 \mathrm{~b}$ & $4.00 \mathrm{ab}$ & $4.97 \mathrm{~b}$ \\
\hline $\mathrm{T}_{4}$ & & 10 & $0.52 \mathrm{ab}$ & 1.46 & 2.17 & 2.93 & $3.57 \mathrm{abc}$ & $3.98 \mathrm{ab}$ & $5.00 \mathrm{~b}$ \\
\hline $\mathrm{T}_{1}$ & \multirow[t]{4}{*}{10} & 0 & $0.50 \mathrm{ab}$ & 1.47 & 2.20 & 2.90 & $3.50 \mathrm{bc}$ & $3.93 \mathrm{ab}$ & $5.22 \mathrm{~b}$ \\
\hline $\mathrm{T}_{2}$ & & 1 & $0.52 \mathrm{ab}$ & 1.50 & 2.15 & 2.87 & $3.53 \mathrm{abc}$ & $3.92 \mathrm{ab}$ & $5.00 \mathrm{~b}$ \\
\hline $\mathrm{T}_{3}$ & & 5 & $0.67 \mathrm{a}$ & 1.66 & 2.37 & 3.00 & $3.70 \mathrm{a}$ & $4.22 \mathrm{a}$ & $6.72 \mathrm{a}$ \\
\hline $\mathrm{T}_{4}$ & & 10 & $0.52 \mathrm{ab}$ & 1.47 & 2.23 & 2.90 & $3.53 \mathrm{abc}$ & $3.87 \mathrm{ab}$ & $5.08 \mathrm{~b}$ \\
\hline $\mathrm{T}_{1}$ & \multirow[t]{4}{*}{20} & 0 & $0.48 \mathrm{~b}$ & 1.45 & 2.13 & 2.87 & $3.53 \mathrm{abc}$ & $3.92 \mathrm{ab}$ & $4.98 \mathrm{~b}$ \\
\hline $\mathrm{T}_{2}$ & & 1 & $0.50 \mathrm{ab}$ & 1.52 & 2.20 & 2.90 & $3.57 \mathrm{abc}$ & $3.93 \mathrm{ab}$ & $4.97 \mathrm{~b}$ \\
\hline $\mathrm{T}_{3}$ & & 5 & $0.53 \mathrm{ab}$ & 1.57 & 2.32 & 2.97 & $3.60 \mathrm{abc}$ & $3.98 \mathrm{ab}$ & $5.03 \mathrm{~b}$ \\
\hline $\mathrm{T}_{4}$ & & 10 & $0.57 \mathrm{ab}$ & 1.50 & 2.25 & 2.90 & $3.63 \mathrm{ab}$ & $3.97 \mathrm{ab}$ & $4.97 \mathrm{~b}$ \\
\hline
\end{tabular}

The common letter(s) in a column did not differ at the level of 5\% probability as per DMRT.

From the above study, it may be concluded that among three varieties and media, Oyster was the best variety and YPDA was the superior media for mushroom cultivation. Malt extract supplemented with $10 \mathrm{ppm}$ IAA+ $5 \mathrm{ppm} \mathrm{NAA}$ as found to be the best for mucelial colony proliferation of Button mushroom.

\section{References}

Alam, S. M., and Saboohi, R. 2001. Importance of mushroom. WWW. mush-world_com. htm.

Chodchoi, C. 1986. Effects of growth regulators compounds on yield and size of the commercial mushroom (Auricularia polytricha). Proceeding of the $24^{\text {th }}$ National Congress, Bangkok, pp127-134.

Gomez, K.A. and Gomez, A.A. 1984. Statistical procedure for Agricultural Research ( $\left.2^{\text {nd }} e d n\right)$. John Willy and Sons. New York. 680p.

Islam, M.S., Islam, M.M., Al Mansur, M.A.Z. and Ali, M. S. 2007. Study on mycelial growth in different mushroom species and spawn production of Oyster mushroom in different substrate. Bangladesh J. Agril. Sci. 34(1):19-22.

Khandakar, J. 2004. Effect of media composition and growth regulators on mycelial growth and spawn production of three mushroom species. MS Thesis, Department of Biotechnology, BAU, Mymensingh.
Maniruzzaman, M. 2004. Influence of media composition and growth regulators on mycelial growth and spawn production of three mushroom species. MS Thesis, Department of Biotechnology, BAU, Mymensingh.

Mori, K. 1986. Cultivated mushrooms in Japan. Prodc. Int'l Sym. Scientific and Technical aspects of cultivating edible fungi. Penna State Univ.,USA.

Nasim, G., Malik, S.H., Bajwa, R., Afzal, M. and Mianm, S.W. 2001. Effect of three different cultural media on mycelial growth of Oyster and Chinese mushroom. Online Journal Biological. Sciences. 1(12), 1130-1131.

Siddiqui, A.B. 2002. Mushroom Production Technology. IHAND Project, GOB/UNDP/FAO, Rangdhanu Printers, pp1-14.

World Bank, 1992. World Development Reports. Oxford University Press, Inc., New York.

World Bank. 2004. World Development Reports. Oxford University Press, Inc., New York. 